\title{
AKTIVITAS GLUTATION PEROKSIDASE DAN KADAR GULA DARAH TIKUS DIABETES YANG DIBERI EKSTRAK DAUN KAPULAGA (Amomum cardamomum)
}

\author{
HAFSAH RIYANTI, SORTA BASAR IDA SiMANJUNTAK, HERY WinARSI
}

Fakultas Biologi, Universitas Jenderal Soedirman, Jalan dr. Suparno 63 Purwokerto 53122

\section{A B S T R A C T}

Oxidative stress in a patient with diabetes known to decrease the activity of GSH-PX and increase the level of blood glucose. Glibenclamide is commonly used by patients with diabetes to lower the blood glucose. However, the long-term use of glibenclamide may induce the damage of pancreatic $\beta$-cells. The extract containing flavonoids and vitamin $C$ of cardamoms leaf can reduce free radicals. The effect of cardamoms leaf extract on the enzymes activity and the level of blood glucose in diabetic rats is yet unknown. The aim of this study was to examine the effect of cardamoms leaf extract administration in the GSH-PX activities and the level of blood glucose of diabetic rats. The method used in this study was experimental with completely randomized design (CRD). There were three groups with five replicates for each. The first group, diabetic rats as control group were given no treatment; the second group, diabetic rats were given cardamoms leaf extract at the dose of $100 \mathrm{mg} / \mathrm{kg}$ of body weight; the third group, the diabetic rat were given glibenclamide at the dose of $2 \mathrm{mg} / \mathrm{kg}$ of body weight. Blood samples were taken three times at 0,7 , and 14 days after each treatment. Parameters measured were GSH-PX activity and the level of blood glucose. The data were analyzed using ANOVA F-test with a confidence level of $95 \%$. The result of this study showed that the cardamoms leaf extract treatment decreased the activity of GSH-PX activity and decreased the level of blood glucose at a significant level $(\mathrm{p}<0.05)$ from 278.8 to $101.4 \mathrm{mg} / \mathrm{dl}$.

KEY WORDS: diabetic-rats, cardamom-leaf-extract, GSH-PX, blood-glucose

Corresponding Author: SORTA BASAR IDA SIMANJUNTAK | email: sortabida@gmail.com

\section{PENDAHULUAN}

Dibetes melitus dikategorikan sebagai penyakit yang diakibatkan adanya kerusakan dari sekresi insulin, aksi insulin, ataupun keduanya (ADA, 2006). Penyakit ini dapat dicirikan dengan terjadinya hiperglikemia (Nair et al., 2012). Hiperglikemia kronis dapat menyebabkan kerusakan, disfungsi berbagai macam organ khususnya mata, ginjal, saraf, jantung dan pembuluh darah (ADA, 2006), serta menyebabkan stres oksidatif (Gumieniczek et al., 2002).

Stres oksidatif dapat menurunkan status antioksidan dan memicu perkembangan penyakit yang terjadi akibat peningkatan produksi radikal bebas (Sujith et al., 2011), diantaranya adalah diabetes (Gumieniczek et al., 2002). Tubuh dalam keadaan normal terlindungi dari stres oksidatif oleh antioksidan seperti SOD, katalase, GSH-PX, Gred, GSH, asam urat, dan bilirubin ( Nair et al., 2012). Glutation peroksidase (GSH-PX) yang merupakan antioksidan enzimatik mampu mendetoksifikasi hidrogen peroksida dan lipid hidroperoksida dengan mereduksi glutation (Odzen et al., 2002), serta mencegah pembentukan radikal bebas baru, atau mengubah radikal bebas yang telah terbentuk menjadi molekul yang kurang reaktif (Chevion et al., 2003). Status GSHPX turun dalam kondisi diabetes (Pasaoglu et al., 2004).

Penderita diabetes melitus tipe-2 biasanya mengkonsumsi glibenklamid untuk menurunkan kadar glukosa darah dikarenakan mampu menstimuli sekresi insulin (Baroroh et al., 2011). Pemberian glibenklamid secara terus menerus dapat menimbulkan degranulasi pada sel-sel $\beta$-pankreas (Ling et al., 2006). Tanaman herbal dapat dijadikan alternatif dalam pengobatan karena memiliki kandungan antioksidan yang dapat menjaga kesehatan tanpa menimbulkan efek toksisitas (Jain, 2011). Salah satunya adalah daun kapulaga (Amomum cardamomun) yang dilaporkan Winarsi et al. (2012) memiliki senyawa flavonoid $126,9 \mathrm{mg} / \mathrm{g}$ ekstrak dan vitamin C $19 \mathrm{mg} / \mathrm{g}$ ekstrak. Penelitian sebelumnya menunjukan bahwa kapulaga mengurangi efek inflamasi dan sebagai obat terapi pada penyakit asma, karena memiliki potensi untuk mengurangi tingkat ROS, dan sitokin yang diproduksi oleh $\mathrm{T}$ helper (Shivakumar \& Shalam, 2012), akibat stres oksidatif.

Tujuan penelitian ini adalah mengetahui efek pemberian ekstrak daun kapulaga terhadap aktivitas glutation peroksidase dan kadar gula darah tikus diabetes. Manfaat penelitian ini diharapkan dapat memberikan informasi mengenai efek pemberian ekstrak daun kapulaga (Amomum cardamomum) untuk memperbaiki status antioksidan tikus diabetes dilihat dari aktivitas glutation peroksidase (GSH-PX) dan kadar glukosa darah.

\section{ME T O DE}

Penelitian ini menggunakan 15 ekor tikus galus Sprague Dawley jantan berumur 2-3 bulan, aloksan, glibenklamid, ekstrak daun kapulaga, pakan dan minum. Alat yang digunakan adalah spuit injection, sonde, botol minum, kandang pemeliharaan, tabung penampung darah dan sentrifuge. Penelitian ini dilakukan selama dua bulan sejak Oktober 2012-Februari 2013.

Penelitian dilakukan secara eksperimental dengan Rancangan Acak Lengkap (RAL) yang dibagi menjadi tiga perlakuan yaitu tikus diabetes tanpa perlakuan (kontrol), tikus diabetes yang diberi glibenklamid dan tikus diabetes yang diberi ekstrak daun kapulaga. Perlakuan ekstrak daun kapulaga dengan dosis $100 \mathrm{mg} / \mathrm{kg}$ berat tubuh dan 
perlakuan glibenklamid dengan dosis $2 \mathrm{mg} / \mathrm{kg}$ berat tubuh. Masing-masing perlakuan menggunakan 5 ekor tikus. Parameter yang diukur adalah aktivitas glutation peroksidase (nmol/mg/menit) dan kadar gula darah (mg/dl).

Tikus Sprague dawley jantan dipuasakan selama 24 jam kemudian diinjeksi dengan aloksan monohidrat yang dilarutkan dalam larutan $\mathrm{NaCl}$ fisiologis steril dengan dosis $120 \mathrm{mg} / \mathrm{kg}$ bb secara intraperitoneal (Kim et al., 2006). Pengukuran kadar gula darah dilakukan pada hari ketujuh setelah induksi aloksan. Kisaran diabetogenik aloksan untuk memperlihatkan aktivitas toksisitas antara $180-200 \mathrm{mg} / \mathrm{dl}$ (Jelodar et al., 2007), namun untuk ditetapkan dabetes dan digunakan sebagai hewan uji diambil yang kadar glukosa darah $\geq 200 \mathrm{mg} / \mathrm{dl}$.

Ekstrak daun kapulaga yang akan diberikan sebelumnya di larutkan dengan aquabides, kemudian diberikan secara oral dengan dosis $100 \mathrm{mg} / \mathrm{kg}$ berat badan tikus. Obat (glibenklamid) diberikan dengan dosis $2 \mathrm{mg} / \mathrm{kg}$ berat badan tikus (Kim et al, 2006). Air dan pakan standar diberikan secara ad libitum selama masa percobaan. Tikus dibagi ke dalam tiga pelakuan, perlakuan pertama sebanyak 5 ekor tikus yang tidak diberi perlakuan (kontrol), perlakuan kedua sebanyak 5 ekor tikus diabetes diberi glibenklamid dengan kode G1-5, dan perlakuan ketiga sebanyak 5 ekor tikus diabetes diberi ekstrak daun kapulaga dengan kode K1-5. Perlakuan ekstrak daun kapulaga maupun glibenklamid pada masing-masing perlakuan diberikan pada pagi hari selama dua minggu.

Pengambilan sampel plasma darah untuk pengukuran aktivitas enzim glutation peroksidase dilakukan pada hari ke-0, ke-7 dan ke-14. Sampel darah tikus diambil melalui vena orbital dengan menggunakan pipet kapiler hematokrit merk Nesco sebanyak 1 cc. Darah yang telah ditampung selanjutnya di sentrifus untuk mendapatkan plasma selama 10 menit dengan kecepatan $3.000 \mathrm{rpm}$. Plasma yang sudah terpisah dipipet kedalam tabung ependorf lain dan siap untuk diuji.

Pengukuran kadar gula darah tikus menurut Soemardji (2004) dilakukan menggunakan Glucose test merk Nesco. Tikus yang akan diuji gula darahnya, sebelumnya bagian ekor yang akan dipotong, dibasahi dengan alkohol 70\% kemudian digunting, tetesan darah pertama dibuang, tetesan darah berikutnya akan diserap oleh test strip. Pendarahan tikus dihentikan, tunggu 5 detik sampai pada layar Gluco test muncul kadar gula darah dalam satuan $\mathrm{mg} / \mathrm{dl}$. Pengukuran aktvitas GSH-PX menggunakan metode Xia et al (1995).

Data yang diperoleh dianalisis menggunakan analisis ragam (ANOVA) menggunakan uji $\mathrm{F}$ dengan tingkat kepercayaan 95\%. Apabila antar perlakuan terdapat perbedaan yang bermakna, dilanjutkan dengan uji Beda Nyata Terkecil (BNT).

\section{HAS IL DAN PEMBAHASAN}

Aktivitas Glutation Peroksidase (GSH-PX) tikus diabetes galur Sprague dawley yang diinduksi aloksan sebesar $18,34 \mathrm{nmol} / \mathrm{mg} / \mathrm{menit}$ ternyata lebih rendah dibandingkan tikus normal $(86,6 \mathrm{nmol} / \mathrm{mg} / \mathrm{menit})$ (Winarsi et al., 2012). Moussa (2008) bahwa dalam tubuh penderita diabetes aktivitas GSH-PX menurun. Pemberian aloksan yang merupakan derivat asam urat menyebabkan nekrosis sel-sel $\beta$ pankreas akibat meningkatnya stres oksidatif (Euteuk, 2010), sehingga sekresi insulin akan menurun dan mengakibatkan hiperglikemia (Gong et al., 2012).
Perbaikan aktivitas GSH-PX tikus diabetes dalam penelitian ini dilakukan dengan pemberian glibenklamid dan EDK. Aktivitas GSH-PX setelah satu minggu pertama pada kelompok tikus yang diberi glibenklamid menunjukkan adanya peningkatan dibandingkan saat awalnya. Begitu pula dengan perlakuan EDK. Namun, berdasarkan analisis kemaknaan ANOVA dengan uji F tidak berbeda nyata ( $p>0,05)$.

Pemberian glibenklamid setelah satu minggu berikutnya menunjukan aktivitas GSH-PX menurun, berbeda halnya dengan pemberian EDK yang aktivitasnya meningkat dari 29,40 menjadi 47,97 $\mathrm{nmol} / \mathrm{mg} / \mathrm{menit}$ (Gambar 1). Meskipun ada peningkatan namun berdasarkan analisis kemaknaan ANOVA tidak berbeda nyata $(\mathrm{p}>0,05)$.

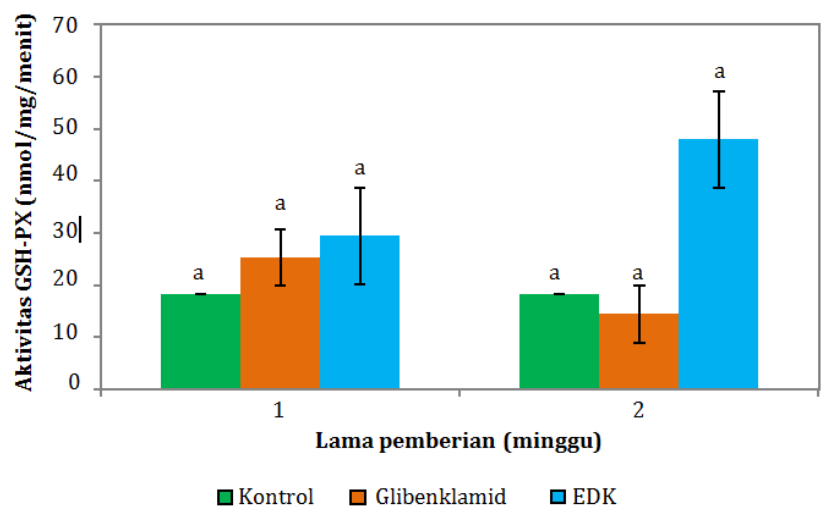

Gambar 1. Aktivitas GSH-PX Tikus Diabetes Keterangan: grafik yang diikuti huruf sama menunjukkan tidak ada perbedaan yang nyata pada uji BNT $5 \%(p>0,05)$ setiap perlakuan

Perlakuan glibenklamid pada tikus diabetes tidak mempengaruhi aktivitas GSH-PX. Ling et al. (2006) menambahkan pemberian glibenklamid pada penderita diabetes hanya mampu memperbaiki sekresi insulin untuk menurunkan kadar glukosa darah. Aktivitas antioksidannya. Berbeda halnya dengan perlakuan EDK pada tikus diabetes yang menunjukan adanya peningkatan aktivitas GSH-PX baik satu maupun dua minggu setelah intervensi. Sesuai dengan hasil penelitian yang dilakukan Kaleem et al. (2006), memberikan ekstrak daun Srikaya (Anona squamosa) dan Kalaivani et al. (2008), memberikan ekstrak daun Cassia (Cassia auriculata) pada tikus diabetes, ternyata dapat meningkatkan aktivitas GSH-PX. Demikian pula yang telah dilakukan Dhuley (1999), bahwa biji kapulaga yang diberikan kepada tikus dengan pakan tinggi lemak, mampu meningkatkan aktivitas GSH dalam darah. Bhattacharjee et al. (2007), menyatakan didalam biji kapulaga terdapat senyawa flavonoid, dapat menetralkan lipid peroksida dan hidrogen peroksida.

Selain flavonoid juga terdapat vitamin C yang dalam EDK (Winarsi et al., 2012). Kandungan vitamin C dalam EDK diduga mampu memperkuat aktivitas GSH-PX. Seperti penelitian yang dilakukan oleh Day dan Lal (2012) pemberian vitamin C mampu meningkatkan aktivitas GSH-PX secara signifikan. 
Pemberian EDK yang memiliki kandungan flavonoid dan vitamin $\mathrm{C}$ sudah memperlihatkan adanya peningkatan aktivitas GSH-PX. Tampak bahwa kapulaga sebagai tanaman dengan kandungan antioksidan memiliki kemampuan untuk memperbaiki kerja antioksidan enzimatis.

Kadar gula darah tikus diabetes yang diinduksi aloksan sebelum diberi perlakuan sebesar 287.8 mg/dl. Kadar gula tersebut ternyata lebih tinggi dibandingkan tikus normal $(110 \mathrm{mg} / \mathrm{dl})$ (Winarsi et al., 2012). Aloksan bersifat toksik dan selektif terhadap sel $\beta$ pankreas yang memproduksi insulin, karena terakumulasinya aloksan melalui glukosa transporter yaitu GLUT2. Terakumulasinya aloksan pada sel $\beta$ pankreas dikarenakan aloksan memiliki sifat yang analog dengan glukosa, sehingga diterima oleh GLUT2 dan dapat masuk kedalam membran plasma lipid bilayer sel $\beta$ pankreas. Akibat dengan masuknya aloksan kedalam sel $\beta$ pankreas adalah kerusakan granula-granula penghasil insulin (Lenzen, 2007), dan naiknya kadar gula darah.

Perlakuan glibenklamid dan EDK pada tikus diabetes dalam menurunkan kadar gula darah setelah pemberian satu minggu menujukan hasil yang berbeda $(p<0,05)$. Setelah dua minggu perlakuan glibenklamid dan EDK menujukan hasil yang berbeda nyata $(\mathrm{p}<0,05)$ dalam menurunkan kadar gula darah tikus diabetes (Gambar 2).

Perlakuan glibenklamid yang merupakan golongan sulfonylurea, merupakan obat pilihan bagi penderita diabetes dewasa yang terbukti mampu menurunkan kadar gula darah menjadi normal. Glibenklamid bekerja merangsang sekresi insulin di kelenjar pancreas (Departemen Kesehatan RI, 2005).

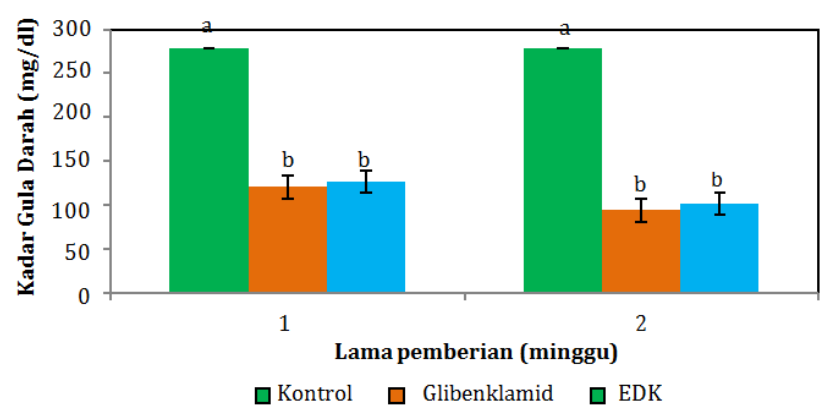

Gambar 2. Kadar Gula Darah Tikus Diabetes. Keterangan: grafik yang diikuti huruf sama menunjukkan hasil yang berbeda nyata pada uji BNT 5\%(p<0,05) setiap perlakuan

Pemberian EDK pada tikus diabetes juga menunjukan penurunan, seperti penelitian yang dilakukan Elshater et al. (2009) dan Zainab et al. (2006), berupa ekstrak etanol jahe (Zingiber officinale) yang menunjukan penurunan kada gula darah. Elshater et al. (2009) menyatakan bahwa jahe mengandung senyawa fenolik (gingerol, shagaol, zingerone, dan paradol) yang dapat memperbaiki sekresi insulin sel $\beta$ pankreas. Raj et al. (2011) menyatakan, pemberian ekstrak etanol rhizom lengkuas (Alpinia calcarata) yang mengandung senyawa flavonoid, alkaloid, dan kumarin yang memiliki fungsi yang sama dengan ekstrak etanol jahe.
Sifat vitamin C sebagai antioksidan yang kuat mampu meredam ROS yang mengakibatkan kerusakan jaringan pada penderita diabetes (Lee et al., 2004). Penelitian yang dilakukan Dakhale et al. (2011) menunjukan kombinasi pemberian vitamin C dengan metformin mampu mengontrol kadar gula pada penderita diabetes. ngan metformin mampu mengontrol kadar gula pada penderita diabetes. Metformin yang berkerja memperbaiki transport glukosa kedalam sel-sel otot (Departemen Kesehatan RI, 2005) dan vitamin C yang mampu meredam ROS (Lee et al., 2004), merupakan kombinasi yang baik dalam mengendalikan hiperglikemia yang diakibatkan oleh rusaknya sel $\beta$ pankreas.

\section{K E S I M P U L A N}

Berdasarkan hasil dan pembahasan maka dapat diambil kesimpulan bahwa pemberian ekstrak daun kapulaga pada tikus diabetes belum dapat meningkatkan aktivitas glutation peroksidase (GSHPX) tetapi dapat menurunkan kadar gula darah tikus diabetes. Perlunya penelitian lebih lanjut dengan menggunakan dosis ekstrak daun kapulaga yang lebih tinggi atau mengkombinasikan ekstrak daun kapulaga dan glibenklamid guna memperbaiki status GSH-PX.

\section{AF T AR REFERENSI}

American Diabetes Association (ADA). 2006. Diagnosis and classification of diabetes mellitus. Diabetes Care. 2:43-48.

Baroroh F, Nufrina A, Hari S. 2011. Uji efek antihiperglikemik ekstrak etanol daun Kacapiring (Gardenia augusta, Merr) pada tikus putih jantan galur Wistar. Jurnal Ilmiah Kefarmasian.1(1):43-53.

Bhattacharjee S, Rana T, Sengupta A. 2007. Inhibition of lipid peroxidation and enhancement of GST activity by Cardamom and Cinnamon during chemically induced colon carcinogenesis in Swiss albino mice. Asian Pacific Journal of Cancer Prevention. 8:578-582.

Chevion S, Danny SM, Yuval H, Yoav S, Gilad R, Benny A, Eduard B, Earl RS, Yoram E. 2003. Plasma antioxidant status and cell injury after severe physical exercise. PNAS. 100(9):5119-5123.

Dakhale GN, Chaudhari HV, Shrivastava M. 2011. Supplementation of vitamin $C$ reduces blood glucose and improves glycosylated hemoglobin in type 2 diabetesmellitus: a randomized, doubleblind study. Advances in Pharmacological Sciences. 195-271.

Day L, Lal SS. 2012. Supplementation effect of vitamin C and vitamin E on oxidative stress in post menopausal diabetic woman. The Journal of Diabetic Research. 12(2).

Departemen Kesehatan Republik Indonesia. 2005. Pharmaceutical care untuk penyakit diabetes mellitus. [diakses pada tangal 01 Januari 2013]. Tersedia pada: http://ilmufarmasis. filr.wordpress. com//2011/03/ph-care-dm.pdf.

Dhuley JN. 1999. Anti-oxidant effects of Cinnamon (Cinnamomum verum) bark and greater Cardamom (Amomum subulatum) seeds in rats fed high fat diet. Indian Journal of Experimental Biology.37(3):238-242.

Elshater AA, Muhammad MAS, Mahrous MAM. 2009. Effect of ginger extract consumption on levels of blood glucose, lipid profile and kidney functions in Alloxan induced-diabetic rats. Egyptian Academic Journal Biology. Science. 2(1):153-162.

Eutuk EU. 2010. Animals models for studying diabetes mellitus. Agriculture and Biology Journal of North America. 1(2):130134.

Gong F, Fenglin L, Wanming Z, Jing L, Zhong Z. 2012. Effects of crude flavonoids from Tatary Buckwheat on Alloxan induced oxidative stress in mice. Bangladesh Journal of Pharmacology. $7: 124-130$. 
Gumieniczek A, Hanna H, Zbigniew W, Justyna N. 2002. Changes in antioxidant status of heart muscle tissue in experimental diabetes in rabbits. Acta Biochimica Polonica. 49(2):529-535.

Jain N, Goyal S, Ramawat KG. 2011. Evaluation of antioxidant properties and total phenolic content of Medicinal plants used in diet therapy during postpartum healthcare in Rajasthan. International journal of pharmacy and pharmaceutical sciences. 3(3):248-253.

Jelodar G, Maleki M, Shahram S. 2007. Effect of walnut leaf, coriander and pomegranate on blood glucose and histopathology of pancreas of Alloxan induced diabetic rat. African Journal Traditional Complementary and Alternative Medical.4 (3):299 - 305.

Kalaivani A, Umamaheswari A,Vinayagam A, Kalaivani K. 2008. Anti-hyperglycemic and antioxidant properties of Cassia auriculata leaves and flowers on Alloxan induced diabetic rats. Pharmacologyonline. 1:204-217.

Kaleem M, Asif M, Ahmed QU, Bano B. 2006. Antidiabetic and antioxidant activity Annona squamosa Extract in Streptozotocin-induced diabetic rats. Singapore Medical Journal. 47(8):670.

Kim SJ, Ju BJ, Choi WC, Kin CS. 2006. Hypoglemic and antihyperlipidemic effect of four Korean medical plants in Alloxan induce diabetic rats. American Journal Biochemistry Biotechnology. 2(4):154-160.

Lee D, Folsom AR, Harnack L, Halliwell B, Jacobs DR. 2004. Does supplemental vitamin $\mathrm{C}$ increase cardiovascular disease risk in women with diabetes?. American Journal Clinical Nutrition. 80:1194-200.

Lenzen S. 2007. Alloxan and Streptozotocin diabetes.[ diakses pada tanggal 24 Januari 2013]. Tersedia pada http://www.sawlepzig.de/forschung/projekte/zeitstrukturenendokrinersysteme/endokrinologieiii/endo_07-lenzen.pdf.

Ling Z, Wang Q, Stange G, Veld PI, Pipeleers D. 2006. Glibenclamide treatment recruits $\beta$ cell subpopulation into elevated and sustained basal insulin synthetic activity. Diabetes. 5:78-85.

Moussa SA. 2008. Oxidative stress in diabetes mellitus. Romanian Journal Biophysic. 18(3):225-236.
Nair SP, Shah NC, Shah RM. 2012. Alteration in enzymatic antioxidant defense in diabetes mellitus. Biomedical Research. 23(3):402-404.

Ozden M., Maral H, Akydin D, Cetnalp P, Kalender B. 2002. Erythrocyte glutathione peroxidase activity, plasma malondialdehyde and erythrocyte glutathione levels in hemodialysis and CAPD patients. Clinical Biochemistry. 35:269273.

Paşaoğlu H, Banu S, Neslihan B. 2004. Lipid peroxidation and resistance to oxidation in pantiens with type 2 diabetes mellitus. Tohoku Journal Experimental Medicine. 203:211-218.

Raj N, Nadeem S, Jain S, Raj C, Nandi KCP. 2011. Ameliorative effects of Alpinia calcarata in Alloxan-induced diabetic rats. Digest Journal of Nanomaterials and Biostructures. 6(3):891-897.

Ramakrishna V, Jailkhani R. 2007. Evaluation of oxidative stress in insulin dependent diabetes mellitus (IDDM) patients. Diagnostic Phatology. 2(22):1-6.

Shivakumar L, Shalam. 2012. A short review on management of asthma through alternative therapies. International Journal of Life Sciences Biothecnology and Pharma Reserch. 1(1):22503137.

Soemardji AA. 2004. Penentuan kadar gula darah mencit secara cepat : untuk diterapkan dalam penapisan aktivitas antidiabetes in vivo. Acta Pharmaceutica Indonesia. 29(3):115.

Winarsi H, Sasongko ND, Purwanto A, Nuraeni I. 2012. Minuman berbasis kestrak kapulaga sebagai antioksidan yang berpotensi antidiabetes.Laporan Penelitian MP3EI. LPPM. Universitas Jenderal Soedirman.

Xia E, Govinda R, Holly VR, Ahmad RH, Arlan R. 1995. Activities of antioxidant enzymes in various tissues of male fischer 344 rats are altered by food restriction. Am Ins Nutr. 195-201.

Zainab MA, Martha T, Khaled KA, Riitta PS, Muslim A. 2006. Antidiabetic and hypolipidaemic properties of ginger (Zingiber officinale) in streptozotocin-induced diabetic rats. British Journal of Nutrition. 96:660-666. 